Syntax Fusion : Jurnal Nasional Indonesia

p-ISSN: $x x x x-x x x x$

e-ISSN : $x x x x-x x x x$

Vol. 1, No. 1, Oktober 2020

\title{
PENINGKATAN KEMAMPUAN MENULIS TEKS EDITORIAL DENGAN MODEL KOOPERATIF TIPE THINK-TALK-WRITE (TTW)
}

\section{Ismail Kusmayadi \\ SMAN 1 Banjaran Kab. Bandung}

E-mail: mailkarung@gmail.com

\section{Abstrak}

Penelitian ini berdasarkan dari latar belakang keterampilan merancang atau mengorganisasikan isi secara sistematis, dan model pembelajaran dengan proses penulisan tidak berorientasi terhadap peserta didik. Oleh karena itu, diperlukan upaya untuk meningkatkan kompetensi peserta didik menulis teks editorial. Hasil dalam penelitian ini menunjukkan kepada sebuah pembelajaran model kooperatif tipe "think-talk-write" yang menjadi sebuah alternative untuk meningkatkan suatu peningkatan dalam bentuk intensitas keterampilan dan keterlibatan siswa secara efektif pada keterampilan menulis dengan teks editorial serta dalam berfikir kritis untuk melatih atas permasalahan yang akan terjadi di sekitarnya . Berdasarkan tindakan yang dilakukan pada siklus I, II, dan III terjadi peningkatan ketuntasan belajar. Pada siklus I, ketuntasan belajar mencapai 69,6\%. Kemudian, mengalami peningkatan pada siklus II menjadi 84,78\% serta pada siklus I menjadi 93,47\%. Dengan demikian, keberhasilan menulis teks editorial dan berpikir kritis peserta didik tidak terlepas dari kemampuan guru mengembangkan model pembelajaran kooperatif berorientasi terhadap siswa.

Kata Kunci: Kompetensi Menulis; Teks Editorial; Model Kooperatif.

\section{Pendahuluan}

Pembelajaran dapat dijadikan sebuah arti dengan upaya yang sistematik dan disengaja oleh pendidik untuk menciptakan kondisi-kondisi agar peserta didik melakukan kegiatan belajar. Dalam kegiatan ini terjadi interaksi edukatif antara peserta didik dan pendidik yang dilakukan setiap kegiatan pembelajaran.

Belajar dapat diamanati dari dua segi, yaitu belajar sebagai proses dan belajar sebagai hasil. Sebagai salah satu proses pembelajaran yang merupakan upaya untuk menyesuaikan tingkah laku dinilai wajar, sedangkan hasil adalah perubahan dari tingkah laku yang dapat ditemui dari kegiatan belajar itu sendiri. (Sudjana, $2005 \mathrm{hlm} .8$ )

Kurikulum 2013 dengan mata pelajaran Bahasa Indonesia, secara umum bertujuan untuk peserta didik agar mampu mendengarkan, membaca, serta berbicara dan menulis. Kompetensi dasar dapat berkembang berdasarkan tiga hal dengan ruang lingkup materi 
yang berhubungan dan mendukung atas suatu pengembangan kompetensi dalam pengetahuan berbahasa dan keterampilan berbahasa.

Kompetensi dari sikap dapat dikembangkan melalui kompetensi pengetahuan kebahasaan dan keterampilan bahasa. Lingkup ketiga merupakan sebuah materi bahasa, yaitu pengetahuan tentang bahasa Indonesia, sastra yang meliputi pemahaman, apresiasi, tanggapan, analisis, dan penciptaan karya sastra. Literasi yang meliputi perluasan kompetensi berbahasa Indonesia dalam tujuannyang khususnya berkaitan dengan berbagai macam bacaan dan penulisan.

Khusus dalam pelajaran bahasa Indonesia dapat dilaksanakan dengan melakukan prinsip sebagai berikut.

1. Bahasa merupakan salah satu dalam kegiatan sosial. Pada setiap komunikasi di suatu kegiatan sosial terdapat sebuah tujuan, konteks, dan audiensyang memerlukan pilihan terhadap aspek kebahasaan yang tepat, serta mengungkapkan dengan cara menstruktur yang sesuai agar mudah dipahami.

2. Berkaitan dengan bahan pelajaran bahsa yang dapat digunakan wajib bersifatotentik. Karena dalam pengembangannya didapat dari media masa, tulisan guru di kelas dengan melakukan suatu produksi lisan dan tulisan. Sehingga semua bahan dapat dilakukan bahkan dikelola oleh guru untuk mendapatkan keberhasilan.

3. Proses pembelajaran menekankan aktivitas siswa yang bermakna. Inti dari siswa aktif adalah siswa mengalami proses belajar yang efesien dan efektif secara mental dan eksperiensial.

4. Dalam metode pembelajaran bahasa dan sastra, dikembangkan dalam budaya membaca dan menulis. Di dalam satu tahun dalam sebuah proses pembelajaran, peserta didik diberi sebuah motivasi untuk dapat membaca dengan giat atau paling sedikit 8 buku (sastra dan non sastra) sehingga peserta didik dapat dengan cepat menyelesaikan pendidikan di jenjang SMA/MA dengan sedikitnya membaca 24 judul buku.

Salah satu kompetensi dasar yang sering menghadapi kendala dalam pembelajaran adalah menulis. Sebuah keterampilan menulis tidak akan didapat secara alamiah, melainkan harus melalui beberapa tahap proses belajar dan berlatih. Dengan penguasaan keterampilan menulis diharapkan peserta didik dapat meluapkan isi gagasan, pikiran, dan perasaan yang dimiliki.

Kegiatan menulis yang akan dijadikan pembelajaran dalam penelitian di suatu tindakan kelas adalah menulis teks editorial. Kendala menyusun teks editorial berdampak pada sulitnya peserta didik mengungkapkan gagasan solutif terhadap suatu permasalahan yang terjadi disekitarnya. Teks editorial sangat erat kaitannya dengan surat kabar (cetak atau digital) sehingga membutuhkan pengetahuan dan kompetensi yang baik mengenai penyusunan teks editorial.

Teks editorial atau tajuk rencana adalah suatu bentuk opini yang lazim ditemukan pada surat kabar, tabloid, atau majalah. Dengan mencerminkan sebuah tajuk rencana tentang aspirasi, pendapat, dan sikap resmi pada suatu media terhadap persoalan potensial yang akan terjadi pada masyarakat (Sumadiria, 2005, p. 81) 
Teks editorial atau tajuk rencana merupakan tulisan khas redaksi yang mencerminkan kepribadian surat kabar yang bersangkutan. Misalnya, pers berkualitas senantiasa berhati-hati dalam menyampaikan kritik, normative yang cenderung pada kenservatif untuk menghindari pendekatan kritik dengan sifat yang fulgar. Dalam pemuatan editorialnya, pers papan atas lebih mempertimbangkan aspek politis dibandingkan aspek sosiologis.

Teks editorial dapat dijadikan sarana efektif oleh peserta didik dalam mengungkapkan gagasan, solusi, dan kritik terhadap permasalahan aktual di masyarakat. Hal ini pun dapat dimanfaatkan untuk melatih kemampuan berpikir kritis (critical thingking). Peserta didik akan lebih peka dan peduli terhadap permasalahan yang terjadi di lingkungannya.

Mengingat proses belajar peserta didik masih bergantung motivasi, maka penulis merasa perlu untuk memilih model pembelajaran yang mencakup keduanya, yaitu pembelajaran yang bersifat kooperatif dan pembelajaran yang berpusat pada peserta didik serta mampu mengonstruksi pengetahuan konsep peserta didik. Untuk itu, peneliti menerapkan tentang pembelajaran think-walk-write yang termasuk pada sebuah proses pembelajaran kooperatif yang memang terpusat kepada peserta didik. Selain itu, dalam tinjauan dari langkah pembelajaran yang beraliran kontruktivisme.untuk itu, teknik ini akan dipergunakan dalam pembelajaran menulis/merancang teks editorial.

Kelas yang dijadikan objek dalam penelitian ini adalah kelas XII MIPA 5 SMA Pasundan 1 Bandung. Peserta didik di kelas XII MIPA 5 masih mengalami kesulitan dalam mengungkapkan gagasan dalam penulisan teks editorial. Ketuntasan dalam pembelajaran ini kurang dari $85 \%$. Hal ini patut menjadi perhatian pendidik, sebab menjadi sebuah pemahaman dalam mengakses teks editorial yang masih kurang. Apalagi peserta didik diminta untuk menulis teks editorial tersebut.

Berdasarkan latar belakang tersebut, penulis ingin mengetahui kendala dan penyebab ketidaktuntasan materi ini serta berupaya mencari solusi agar peserta didik kelas XII MIPA 5 mampu meningkatkan kemampuan menulis teks editorial. Penelitian tindakan kelas ini akan penulis tuangkan dalam karya ilmiah dengan judul "Peningkatan Kemampuan Menulis Teks Editorial dengan Model Kooperatif Tipe Think-Talk-Wrtie (TTW).”

\section{Metode Penelitian}

Penelitian ini yaitu sebuah tindakan kelas atau Classroom Action Research. Menurut (Arikunto, 2009, p. 3) dalam penelitian tindakan kelas ini merupakan salah satu pencermatan terhadap kegiatan belajar berupa tindakan yang muncul dan terjadi pada sebuah kelas secara bersamaan.

Penelitian tindakan kelas (PTK) dilaksanakan sebagai strategi pemecahan masalah dengan memanfaatkan tindakan nyata, kemudian merefleksi terhadap hasil tindakan. Penelitian tindakan ini terlebih sangatlah cocok untuk meningkatkan suatu proses dan kualitas subjek yang diteliti. Penelitian ini dilaksanakan untuk meningkatkan aktivitas dalam pembelajaran menulis/ merancang teks editorial dengan menerapkan proses 
kooperatif tipe think-talk-write (TTW). Subjek penelitian adalah peserta didik kelas XII IPA 5 SMA Pasundan 1 Bandung mata pelajaran bahasa Indonesia pada KD 4.9 tentang merancang teks editorial.

Tempat penelitian adalah tempat yang digunakan dalam melakukan penelitian untuk memperoleh data yang diinginkan. Penelitian ini bertempat di SMA Pasundan 1 Bandung Tahun Pelajaran 2019/ 2020. Pemilihan tempat itu didasarkan pada pertimbangan (1) efektivitas waktu dan tempat, (2) memudahkan koordinasi dengan pihak sekolah, dan (3) memahami kondisi riil potensi pendidik dan peserta didik sehingga penulis merasa perlu melakukan riset untuk meningkatkan kemampuan mengajar sehingga akan berdampak pada peningkatan kemampuan siswa memahami materi pelajaran.

Waktu penelitian adalah waktu yang berlangsung saat penelitian ini dilangsungkan. Penelitian ini dilaksanakan pada 30 September 2019 sampai 19 Oktober 2019, semester ganjil Tahun Pelajaran 2019/2020.

Penelitian ini adalah penelitian tindakan kelas, model Stephen Kemmis dan Mc Taggart dalam (Suranto, 2002 hlm. 49). Model ini menggunakan salah satu sistem spiral refleksi yang dimulai dari sebuah rencana, tindakan, pengamatan, dan perencanaan yang merupakan dasar untuk merancang sebuah pemecahan masalah.

Penelitian tindakan kelas (PTK) merupakan salah satu dari pendekatan untuk meneliti kelas atau sekolah yang melakukan pemecahan di berbagai masalah yang digunakan dalam rangka untuk meningkatkan kualitas pendidikan (Tim Pelatih Proyek PGSM, 1999 hlm. 1-2).

Instrumen yang digunakan dalam penelitian ini antara lain sebagai berikut.

a. Lembar observasi

Lembar observasi merupakan catatan yang menggambarkan tingkat aktivitas peserta didik dalam proses pembelajaran. Observasi dilakukan dengan melakukan pengamatan dan pencatatan mengenai kegiatan pendidik dan pserta didik selama pembelajaran Bahasa Indonesia berlangsung dengan menggunakan model kooperatif tipe think-talk-write.

\section{b. Tes}

Tes digunakan dalam dalam tujuanuntuk mengukur hasil sebagai tindak lanjut dari sebuah pembelajaran yang telah dilakukan. Tes dilakukan pada setiap akhir pembelajaran untuk mengetahui tingkatan efektivitas.

Data yang diambil adalah data kualitatif dan data kuantitatif. Menurut (Sugiyono, 2010), aktivitas untuk menganalisis sebuah data dapat diliputi dari data reduction, data display, dan data concluscion drawing/verification. Adapun langkah-langkahnya sebagai berikut.

1. Mereduksi data, yaitu merangkum, memilih yang pokok, fokus pada hal-hal yang penting, mencari tema dan pola.

2. Data display (penyajian data, teks yang bersifat naratif, berupa grafik atau tabel). 
3. Conclucion drawing/verification adalah penarikan kesimpulan dan verifikasi. Penarikan kesimpulan yang memungkinkan dengan menjawab rumusan masalah yang telah dirumuskan sejak awal.

Teknik analisis data dilakukan secara kualitatif maupun kuantitatif.

\section{Secara Kualitatif}

Data kualitatif diperoleh dari data nontes, yaitu data observasi, angket, dan dokumentasi foto. Analisis data dilakukan dengan menelaah seluruh data yang diperoleh, menyusunnya dalam satuan-satuan, dan dikategorisasikan.

Hasil analisis data secara kualitatif digunakan untuk mengetahui perubahan perilaku siswa pada pembelajaran siklus I, II, dan siklus III, serta untuk mengetahui efektivitas penggunaan model kooperatif tipe think-talk-write dalam peningkatan kemampuan merancang teks editorial.

\section{Secara Kuantitatif}

Dari hasil tes yang diperoleh oleh data kuantitatif dengan menulis teks editorial pada siklus I dan menulis teks editorial dengan tipe dan model think-talk-write pada siklus II, dan III. Menganalisis data secara kuantitatif atau deskripstif yang dilakukan dengan menghitung nilai masing-masing aspek, merekap nilai siswa, menghitung nilai rata-rata siswa, dan menghitung presentase nilai.

\section{Hasil dan Pembahasan}

\section{Siklus 1}

Kegiatan awal pembelajaran dimulai dengan mengondisikan peserta didik ke dalam situasi pembelajaran yang kondusif, dengan mengatur tempat duduk, memeriksa kelengkapan belajar dan berdoa bersama, lalu mengecek kehadiran peserta didik. Kemudian, peserta didik mendapat motivasi dan semangat dari pendidik untuk menjadikan pembelajaran ini bermakna. Lalu pendidik menyampaikan tujuan pembelajaran dan memberikan penjelasan tentang manfaat menguasai materi pelajaran. Peserta didik memperhatikan penyampaian pokok-pokok/ cakupan materi pembelajaran.

Pada kegiatan inti pendidik memberikan penjelasan sekilas mengenai tahapan penulisan teks editorial dan struktur yang membangunnya. Kemudian, peserta didik diminta menentukan topik dari permasalahan aktual, faktual, dan atau kontroversial sebagai acuan penulisan teks editorial. Peserta didik diberi keleluasaan untuk menentukan tema dengan harapan mereka dapat menguasai permasalahan yang akan dibahas.

Pendidik meminta peserta didik untuk menulis teks editorial di lembar yang telah disediakan. Peserta didik menentukan topik terlebih dahulu, kemudian mendiskusikannya dengan teman sebangku mengenai topik yang dipilih. Setelah mendapatkan cukup informasi, peserta didik mulai menulis sesuai dengan struktur teks editorial. Peserta didik menuliskan paragraf pertama sebagai pernyataan pendapat (tesis) berkaitan dengan topik yang dipilih. Kemudian, peserta didik menguraikan dengan penjelasan yang dapat dilengkapi data sebagai argumentasi. Tulisan teks editorial diakhiri dengan pernyataan ulang pendapat sebagai penguatan gagasan yang disampaikan. 
Pada akhir pembelajaran, peserta didik melakukan refleksi berkenaan dengan kegiatan pembelajaran menulis teks editorial. Pendidik mencatat dan mencermati kesulitan yang dikemukakan peserta didik saat menulis. Berdasarkan hasil refleksi dan evaluasi, peneliti menemukan beberapa permasalahan sebagai berikut.

1. Umumnya, peserta didik kesulitan untuk memulai menulis.

2. Peserta didik sudah dapat mengidentifikasi teks editorial yang dimuat di surat kabar, tetapi ketika akan menulis sebagian peserta didik merasa tidak yakin bahwa yang akan ditulisnya dapat dikategorikan sebagai teks editorial.

3. Beberapa peserta didik seolah malas untuk berpikir dan mencari data untuk memperkuat argumentasi sehingga opini yang dikemukakan kurang tajam karena hanya sebatas pendapat sesuai pemahamannya.

4. Beberapa peserta didik kurang fokus pada tugas yang diberikan padahal pembelajaran dilaksanakan pada jam pelajaran pertama.

Saat siswa melakukan proses pembelajaran, guru melakukan observasi. Berdasarkan observasi tersebut diketahui bahwa kemampuan guru dalam merancang Rencana Pelaksanaan Pembelajaran mencapai 87\%, sedangkan target minimal 75\%. Ini berarti kemampuan guru dalam merancang Rencana Pelaksanaan Pembelajaran sudah berhasil dengan persentase keberhasilan, kemampuan guru dalam merancang rencana pelaksanaan pembelajaran mencapai kriteria baik. Namun peneliti merasa masih ada beberapa aspek yang masih harus diperbaiki untuk mencapai perencanaan yang maksimal.

Berdasarkan hasil observasi, masih terdapat beberapa kelemahan dalam kejelasan menerangkan materi sesuai tuntutan kompetensi, memaksimalkan penggunaan media, serta belum tampaknya penggunaan model kooperatif tipe think-talk-write.

Pada kesempatan ini, observer pun melakukan pengamatan terhadap aktivitas peserta didik. Hal ini dilakukan untuk mengetahui bagaimana sikap dan respons peserta didik terhadap pembelajaran yang sedang berlangsung. Berikut hasil observasi aktivitas peserta didik selama siklus I berlangsung.

Tabel 1 Hasil Observasi Aktivitas Peserta Didik pada Siklus I

\begin{tabular}{|c|l|c|c|c|c|}
\hline \multirow{2}{*}{ No. } & \multicolumn{1}{|c|}{ Aspek yang Diamati } & \multicolumn{3}{|c|}{ Kriteria } \\
\hline & \multicolumn{1}{|c|}{} & $\mathbf{4}$ & $\mathbf{3}$ & $\mathbf{2}$ & $\mathbf{1}$ \\
\hline 1. & $\begin{array}{l}\text { Peserta didik termotivasi dalam mengikuti } \\
\text { pembelajaran }\end{array}$ & & $\checkmark$ & & \\
\hline 2. & $\begin{array}{l}\text { Peserta didik memberikan respons positif } \\
\text { terhadap pembelajaran merancang teks editorial }\end{array}$ & & $\checkmark$ & & \\
\hline 3. & $\begin{array}{l}\text { Peserta didik memberikan perhatian terhadap } \\
\text { apersepsi dan pemberian acuan yang dilakukan } \\
\text { oleh pendidik }\end{array}$ & & & $\checkmark$ & \\
\hline 4. & $\begin{array}{l}\text { Peserta didik memberikan perhatian terhadap } \\
\text { penjelasan pendidik }\end{array}$ & & & $\checkmark$ & \\
\hline 5. & Peserta didik menguasai materi ajar & & & $\checkmark$ & \\
\hline
\end{tabular}




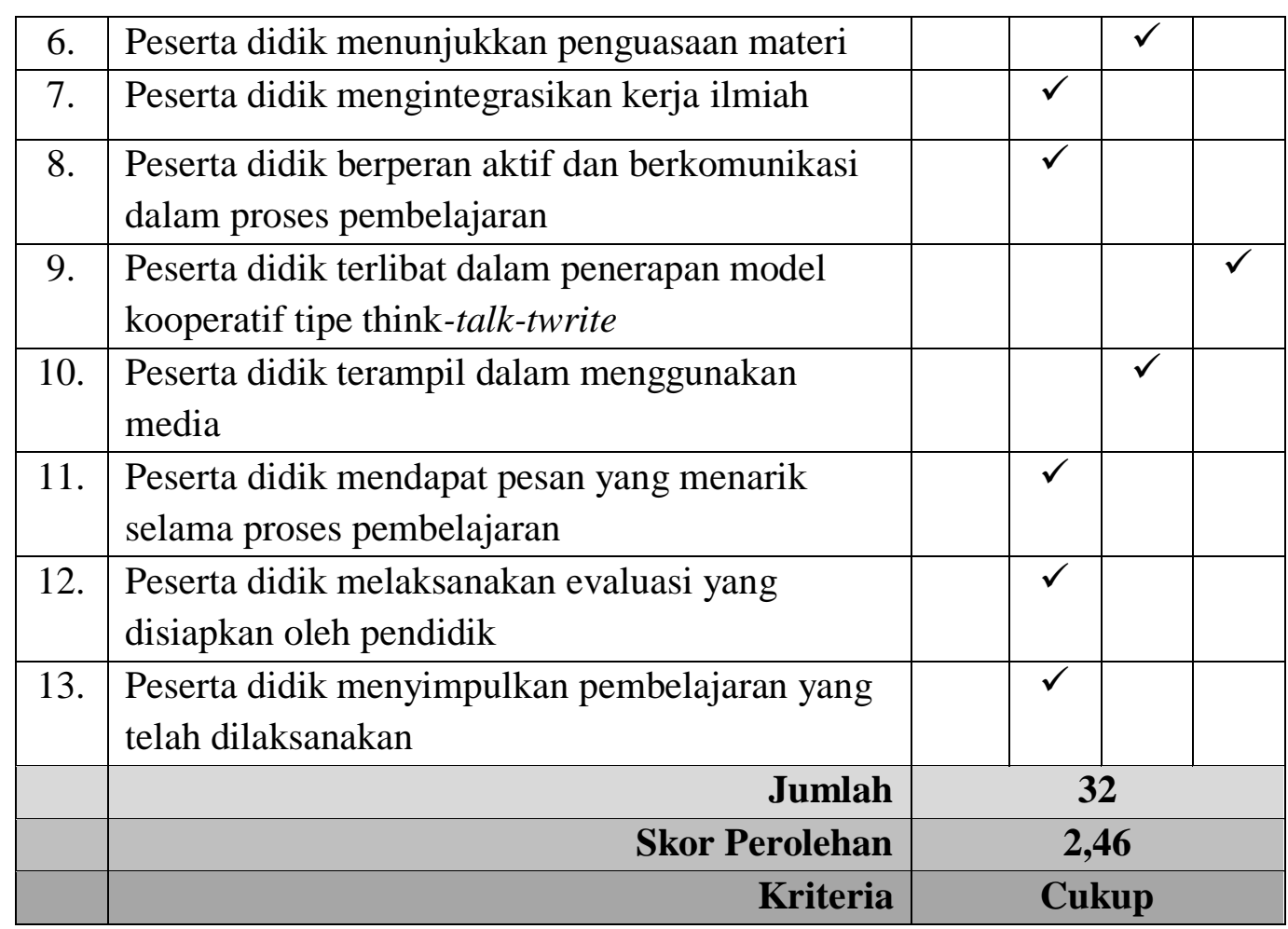

Berdasarkan hasil observasi terhadap aktivitas peserta didik diketahui bahwa respons peserta didik terhadap pembelajaran menulis teks editorial berada pada kategori cukup. Aktivitas peserta didik memberikan perhatian terhadap apersepsi dan pemberian acuan, penjelasan, dan penguasaan materi yang disampaikan pendidik belum memuaskan. Hal ini disebabkan pemahaman peserta didik terhadap penguasaan kemampuan menulis masih kurang. Di sisi lain, pembelajaran yang dilaksanakan pada siklus I belum menerapkan model think-talk-write.

Sementara itu, nilai rata-rata yang diperoleh oleh peserta didik kelas XII MIPA 5 pada siklus I adalah 81,6 dengan presentase jumlah peserta didik yang memenuhi KKM sebanyak 32 orang atau 69,6\%, sedangkan yang tidak memenuhi KKM masih banyak, yakni berjumlah 14 siswa atau 30,4\%. Peserta didik yang tidak memenuhi KKM termasuk yang tidak hadir pada saat pelaksanaan siklus I karena beragai alasan. Peserta didik tersebut tidak melaksanakan tes susulan sehingga dinyatakan tidak tuntas. Dengan demikian, dapat diambil kesimpulan bahwa pembelajaran menulis teks editorial pada siklus I masih belum mencapai batas minimal kelulusan yakni $85 \%$.

\section{Siklus II}

Kegiatan belajar mengajar yang dilaksanakan mengacu pada Rencana Pelaksanaan Pembelajaran (RPP) yang telah dipersiapkan. Model pembelajaran yang digunakan adalah model kooperatif tipe think-talk-write. Perencanaan pada siklus II merupakan hasil refleksi dari siklus I. Adapun perbedaan yang terdapat dalam perencanaan siklus II, yaitu terletak pada model pembelajaran yang diterapkan. Model pembelajaran tersebut 
didasarkan pada temuan siklus I yang menunjukkan bahwa kemampuan peserta didik dalam mengembangkan ide/ gagasan menjadi sebuah tulisan lengkap masih kurang.

Pada siklus II, peserta didik akan melaksanakan pembelajaran menyusun atau menulis teks editorial dengan menerapkan model kooperatif tipe think-talk-write. Menurut Hamdayana (2014 hlm. 221), model think-talk-write setidaknya memiliki dua manfaat, yakni:

a. Pembelajaran berbasis komunikasi dengan strategi TTW akan dapat membantu dalam mengontruksi beberapa pengetahuannya sehingga dalam memahami konsep menjadi lebih baik untuk peserta didik. Peserta didik dapat mengomunikasikan atau mendiskusikan hasil pembelajarnnya kepada temannya dalam segi saling membantu atau bertukar pikiran.

b. Pembelajaran berbasis komunikasi dengan strategi TTW dapat membantu melatih peserta didik untuk menuliskan kembali hasil diskusinya secara sistematis sehingga dapat lebih membantu dan menambah pemahaman dari ideide dengan bentuk tulisan.

Jika pada siklus I belum dijelaskan mengenai tahapan kerja model kooperatif tipe think-talk-write maka peneliti pada siklus II memanfaatkan media power point dalam memberikan penjelasan, arahan tugas, dan contoh.

Pada kegiatan inti, pendidik memberikan penjelasan terlebih dahulu mengenai kegiatan menulis teks editorial dengan menggunakan model think-talk-write. Kemudian, peserta didik diminta untuk menentukan satu permasalahan yang akan dijadikan bahan editorial. Sebagai stimulus, peserta didik dibagi kliping berita di surat kabar yang dapat dijadikan bahan penulisan teks editorial.

Setelah menentukan topik pembahasan berdasarkan kliping berita, , peserta didik berdiskusi dengan teman sebangku untuk memperoleh tambahan informasi, memperoleh masukan mengenai sudut pandang pembahasan, dan merumuskan pengetahuan. Kemudian, peserta didik menyusun kerangka tulisan untuk memudahkan peserta didik. Dengan kerangka tersebut, peserta didik dapat mengumpulkan data dan bahan yang mendukung. Pemaparan yang disampaikan pun akan lebih fokus dan efektif. Kerangka disusun dalam kertas warna yang disediakan pendidik.

Setelah menyusun kerangka, peserta didik mengolah informasi yang telah dihimpun untuk mengembangkan kerangka karangan tersebut menjadi tulisan editorial uang lengkap dan sistematis sesuai dengan strukturnya. Pendidik dapat memberikan arahan dan bimbingan kepada peserta didik yang masih mengalami kesulitan dalam mengembangkan kerangka karangan.

Setelah selesai menulis, peserta didik diminta untuk melakukan penyuntingan terkait penggunaan bahasa, tanda baca, dan keefektifan kalimat. Hal ini penting untuk dilakukan sebagai upaya untuk memberi pemahaman tentang aspek kebahasaan yang terkadang diabaikan dalam proses penulisan karya tulis.

Berdasarkan data observer di atas, kemampuan guru dalam merancang Rencana Pelaksanaan Pembelajaran mencapai 96,6\%, sedangkan target minimal 75\%. Hal ini menujukkan bahwa kemampuan pendidik dalam merancang Rencana Pelaksanaan 
Pembelajaran mengalami peningkatan dibandingkan dengan pada siklus I yang mencapai 87\%. Dengan demikian, dapat dikatakan bahwa perencanaan dan pelaksanaan pembelajaran sudah berhasil dengan mencapai kriteria baik sekali.

Penerapan model kooperatif tipe think-talk-write dalam pembelajaran menulis teks editorial pun dapat dipahami dan direspons dengan baik oleh peserta didik. Hal ini terlihat dari aktivitas kegiatan inti yang memperoleh skor sangat baik.

Berdasarkan tabel tersebut diketahui bahwa nilai rata-rata yang diperoleh oleh peserta didik kelas XII MIPA 5 pada siklus II adalah 83,2 dengan presentase jumlah peserta didik yang memenuhi KKM sebanyak 39 orang atau $84,78 \% \approx 85 \%$, sedangkan yang tidak memenuhi KKM sebanyak 7 orang (15\%). Tujuh peserta didik tersebut termasuk yang tidak hadir sebanyak 4 orang. Peserta didik tersebut tidak melaksanakan tes susulan sehingga dinyatakan tidak tuntas. Dari jumlah peserta didik yang hadir pada kegiatan siklus II, hanya 3 orang yang tidak memenuhi KKM. Dengan demikian, dapat diambil kesimpulan bahwa pembelajaran menulis teks editorial dengan menerapkan model kooperatif tipe think-talk-write pada siklus II sudah mengalami peningkatan yang siginifkan serta dapat mencapai batas minimal kelulusan yakni $85 \%$.

Peningkatan kemampuan peserta didik menulis teks editorial tidak terlepas dari upaya yang dilakukan pendidik dalam menerapkan berbagai pendekatan, metode, dan model yang sesuai dengan karakteristik pelajaran dan pembelajar. Selain itu, pendidik telah mampu merefleksi, mengevaluasi, dan menilai diri sendiri sehingga mampu untuk membuat strategi yang tepat agar tujuan pembelajaran tersebut tercapai/ tuntas.

Faktor lain yang memengaruhi peningkatan ini adalah pendidik yang selalu memotivasi peserta didik agar memiliki semangat belajar. Salah satu bentuk motivasinya adalah selalu menghubungkan kebermanfaatan materi yang dipelajari dengan kehidupan sehari-hari. Hal ini penting sebagai bentuk pembelajaran kontekstual. Peserta didik harus memahami bahwa setiap ilmu yang dipelajari harus sesuai dengan konteksnya sehingga proses pembelajaran tidak terpisah dari kehidupan.

\section{Siklus III}

Perencanaan pada siklus III merupakan hasil refleksi dari siklus II. Adapun perbedaan yang terdapat dalam perencanaan siklus II, yaitu terletak pada pemberian stimulus, sedangkan model pembelajaran yang diterapkan masih sama menggunakan think-talk-write.

Jika pada siklus II stimulus yang diberikan berupa kliping berita di surat kabar maka pada siklus III peserta didik distimulus untuk mencermati lingkungan sekitar untuk dijadikan topik editorial serta berlatih memosisikan peserta didik sebagai redaktur surat kabar yang bertuga mengisi kolom editorial.

Pada kegiatan inti, pendidik mengulas kembali mengenai kegiatan menulis teks editorial denngan model think-talk-write. Kemudian, peserta didik diminta untuk menentukan satu permasalahan yang akan dijadikan bahan editorial. Sebagai stimulus, peserta didik diajak berpikir kritis untuk mengkritisi persoalan-persoalan di sekitar. 
Setelah menentukan topik pembahasan berdasarkan kliping berita, peserta didik berdiskusi dengan teman sebangku untuk memperoleh tambahan informasi, memperoleh masukan mengenai sudut pandang pembahasan, dan merumuskan pengetahuan. Kemudian, peserta didik menyusun kerangka tulisan untuk memudahkan peserta didik. Dengan kerangka tersebut, peserta didik dapat mengumpulkan data dan bahan yang mendukung. Pemaparan yang disampaikan pun akan lebih fokus dan efektif. Kerangka disusun dalam kertas warna yang disediakan pendidik.

Setelah menyusun kerangka, peserta didik mengolah informasi yang telah dihimpun untuk mengembangkan kerangka karangan tersebut menjadi tulisan editorial uang lengkap dan sistematis sesuai dengan strukturnya. Pendidik dapat memberikan arahan dan bimbingan kepada peserta didik yang masih mengalami kesulitan dalam mengembangkan kerangka karangan.

Setelah selesai menulis, peserta didik diminta untuk melakukan penyuntingan terkait penggunaan bahasa, tanda baca, dan keefektifan kalimat. Hal ini penting untuk dilakukan sebagai upaya untuk memberi pemahaman tentang aspek kebahasaan yang terkadang diabaikan dalam proses penulisan karya tulis. Setelah peserta didik mengumpulkan hasil pekerjaannya, pendidik bersama peserta didik menyimpulkan dan melakukan refleksi mengenai materi penulisan teks editorial.

Dalam kegiatan inti, pendidik meminta peserta didik untuk menyusun kerangka tulisan terlebih dahulu. Dengan panduan pendidik, seluruh peserta dapat menyelesaikan kerangka tulisan secara hampir bersamaan. Kemudian, peserta didik dapat mengembangkan kerangka tersebut menjadi tulisan editorial secara utuh dan sistematis. Teks editorial ditulis tangan di kertas folio bergaris.

Berikut hasil observasi pelaksanaan pembelajaran yang dilaksanakan pendidik.

Tabel 2 Hasil Observasi Pelaksanaan Pembelajaran pada Siklus III Berilah tanda centang $(\sqrt{ })$ pada aktivitas sesuai dengan pengamatan Anda.

\begin{tabular}{|c|c|c|c|c|c|}
\hline \multirow{2}{*}{ No } & \multirow{2}{*}{ Indikator/ Aspek yang Dinilai } & \multicolumn{4}{|c|}{ Skor } \\
\hline & & 4 & 3 & 2 & 1 \\
\hline \multirow[t]{3}{*}{1.} & Pra Pembelajaran & & & & \\
\hline & \begin{tabular}{|l} 
a. \\
Kesiapan ruang, alat, dan media pembelajaran
\end{tabular} & $\sqrt{ }$ & & & \\
\hline & b. Memeriksa kesiapan peserta didik & $\sqrt{ }$ & & & \\
\hline \multirow[t]{5}{*}{2} & Kemampuan Membuka Pelajaran & & & & \\
\hline & a. Menarik perhatian peserta didik & $\sqrt{ }$ & & & \\
\hline & b. Memotivasi peserta didik & $\sqrt{ }$ & & & \\
\hline & c. Mengadakan apersepsi & $\sqrt{ }$ & & & \\
\hline & d. Memberi acuan materi yang diajarkan & $\sqrt{ }$ & & & \\
\hline \multirow[t]{3}{*}{3.} & Sikap Guru dalam Proses Pembelajaran & & & & \\
\hline & $\begin{array}{ll}\text { a. Kemampuan dalam berkomunikasi dengan peserta } \\
\text { didik }\end{array}$ & $\sqrt{ }$ & & & \\
\hline & b. Antusiasme mimik dan perhatian & $\sqrt{ }$ & & & \\
\hline
\end{tabular}




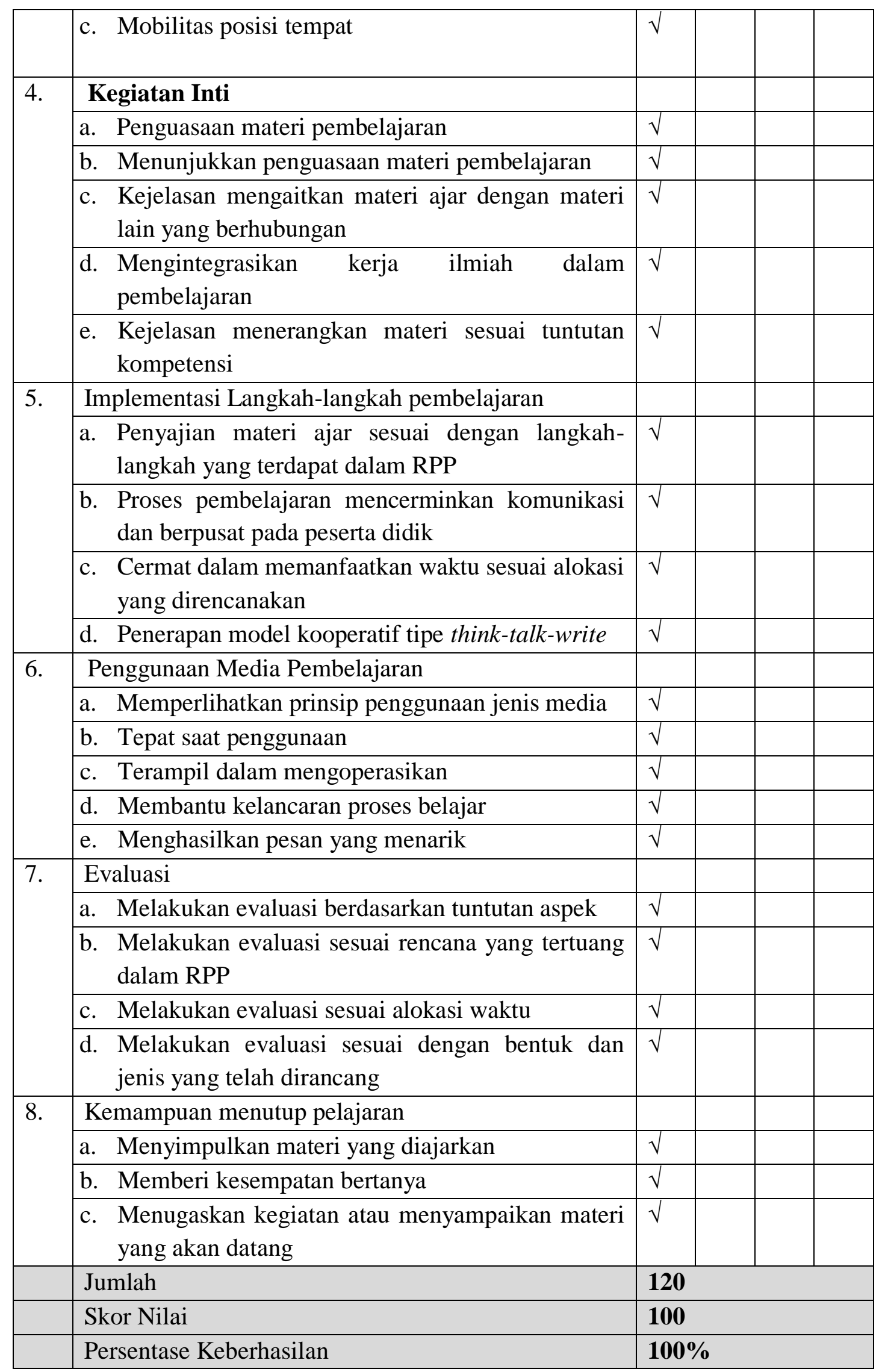


Berdasarkan data observer di atas, kemampuan guru dalam merancang Rencana Pelaksanaan Pembelajaran mencapai $100 \%$, sedangkan target minimal 75\%. Hal ini menunjukkan bahwa kemampuan pendidik dalam merancang Rencana Pelaksanaan Pembelajaran mengalami peningkatan dibandingkan dengan pada siklus II. Dengan demikian, dapat dikatakan bahwa perencanaan dan pelaksanaan pembelajaran sudah berhasil dengan mencapai kriteria baik sekali.

Penerapan model kooperatif tipe think-talk-write dalam pembelajaran menulis teks editorial pun dapat dipahami dan direspons dengan baik oleh peserta didik. Hal ini terlihat dari aktivitas kegiatan inti yang memperoleh skor sangat baik.

Berdasarkan hasil observasi terhadap aktivitas peserta didik diketahui bahwa respons peserta didik terhadap pembelajaran menulis teks editorial mengalami peningkatan, yakni berada pada kategori baik dengan skor 3,92. Aktivitas peserta didik memberikan perhatian terhadap apersepsi dan pemberian acuan, penjelasan, dan penguasaan materi yang disampaikan pendidik sudah memuaskan. Peserta didik sudah mulai memahami dan menguasai materi yang disampaikan menggunakan model kooperatif tipe think-talk-write pada siklus III.

Dalam proses pembelajaran, pendidik mengajak siswa untuk kritis terhadap kondisi lingkungan sekitar, baik lingkungan sekolah maupun lingkungan tempat tinggal peserta didik. Peserta didik diminta untuk menentukan topik yang dianggap menarik, faktual, aktual, dan atau kontroversial. Peserta didik pun diminta menyusun kerangka tulisan dari topik yang telah dipilih.

Setelah peserta didik menyusun kerangka dan mengembangkan kerangka tersebut menjadi teks editorial yang utuh, pendidik memberikan penilaian menggunakan kriteria yang sama dengan penilaian pada siklus II. Hasil evaluasi yang diperoleh pada siklus III ini memberikan deskripsi mengenai hasil pembelajaran dengan menerapkan model kooperatif tipe think-talk-write.

Berdasarkan tabel tersebut diketahui bahwa nilai rata-rata yang diperoleh oleh peserta didik kelas XII MIPA 5 pada siklus III adalah 82,3 dengan presentase jumlah peserta didik yang memenuhi KKM sebanyak 43 orang atau 93,47\%, sedangkan yang tidak memenuhi KKM sebanyak 3 orang $(6,52 \%)$. Tiga peserta didik tersebut yang selama siklus I dan II tidak hadir sehingga belum memahami materi yang disampaikan. Dengan demikian, dapat diambil kesimpulan bahwa pembelajaran menulis teks editorial dengan menerapkan model kooperatif tipe think-talk-write pada siklus III sudah mengalami peningkatan yang siginifkan serta dapat mencapai batas minimal kelulusan yakni $85 \%$.

\section{Simpulan}

\section{Penerapan Model Kooperatif Tipe Think-Talk-Write}

Hasil penelitian berdasarkan siklus I dan II ini menunjukkan bahwa pembelajaran dengan penerapan model kooperatif tipe think-talk-write memiliki dampak positif dalam meningkatkan kemampuan peserta didik menulis teks editorial. Hal ini dapat dilihat dari semakin mantapnya pemahaman peserta didik terhadap materi yang disampaikan 
pendidik (ketuntasan belajar meningkat dari siklus I dan II), dengan persentase ketuntasan pada siklus I yang hanya $69,6 \%$ meningkat menjadi $84,78 \%$ pada siklus II.

\section{Aktivitas Peserta Didik Selama Pembelajaran}

Berdasarkan analisis data hasil observasi, peneliti memperoleh hail bahwa aktivitas peserta didik dalam proses belajar mengajar dengan menerapkan model kooperatif tipe think-talk-write dalam setiap siklus mengalami peningkatan. Peningkatan aktivitas dan respons peserta didik sangat berpengaruh terhadap suasana pembelajaran yang lebih kondusif. Hal ini berdampak positif terhadap kemampuan peserta didik dalam menulis teks editorial. Peserta didik menjadi lebih berpikir kritis, mampu menentukan struktur teks dan kebahasaan teks editorial. Peran pendidik menjadi lebih efektif karena waktu yang ada dapat digunakan juga untuk melakukan pengamatan dan penilaian.

\section{Peningkatan Kemampuan Peserta Didik dalam Menulis Teks Editorial}

Berdasarkan analisis data hasil tes, peneliti memperoleh hasil bahwa kemampuan peserta didik dalam proses pembelajaran bahasa Indonesia pada pokok bahasan menulis teks editorial mengalami peningkatan. Dengan model kooperatif think-talk-write aktivitas yang paling dominan adalah peserta didik mendengarkan/ memperhatikan penjelasan guru, kemudian diskusi antarsiswa, dan menyusun kerangka tulisan terlebih dahulu. Jadi, dapat dikatakan bahwa kemampuan peserta didik dapat dikategorikan meningkat. Pembelajaran tidak lagi berpusat pada guru, tetapi lebih berpusat pada siswa.

Berdasarkan hasil yang diperoleh dapat ditarik kesimpulan bahwa pembelajaran yang berpusat pada peserta didik dengan menerapkan model kooperatif tipe think-talkwrite dalam pembelajaran lebih efektif dibandingkan dengan model diskusi atau ceramah. Pendekatan model kooperatif tipe think-talk-write sangat efektif diterapkan pada pembelajaran menulis teks editorial di kelas XII MIPA 5 SMA Pasundan 1 Bandung.

\section{Bibliografi}

Arikunto, Suharsimi. (2009). Dasar-dasar Evaluasi Pendidikan. 2007. Jakarta: Bumi Aksara.

Budiyanto, Moch. Agus Krisno. (2016). Sintaks 45 Model Pembelajaran dalam Student Centered Learning. Malang: Penerbit Universitas Muhammadiyah Malang.

Fatima, Wa. (2016). "Kemampuan Menentukan Fakta dan Opini dalam Teks Tajuk Rencana Koran Kompas Siswa Kelas XI IPA SMA Negeri 7 Kendari”. Jurnal Bastra Vol. 1 No. 2 Juli 2016.

Fauziati, Emi. (2018). "Peningkatan Kemampuan Memproduksi Teks Editorial Melalui Penggunaan Strategi Think-Talk-Write dengan Model Project Based Learning pada Peserta Didik Kelas XII MIPA 2 Semester 2 SMA Negeri 1 Paguyangan Brebes TAhun Pelajaran 2016/ 2017”. Jurnal Orbith Vol. 4 No. 3 November 2018 hlm. 167-175. 
Ismail Kusmayadi

Hamdayana, Jumanta. (2014). Model dan Metode Pembelajaran Kreatif dan Berkarakter. Bogor: Ghalia Indonesia

Huda, Miftahul. (2014). Model-model Pengajaran dan Pembelajaran. Yogyakarta: Pustaka Pelajar.

Kemdikbud. (2015). Modul Materi Pelatihan Guru Implementasi Kurikulum 2013. Jakarta: Kemdikbud.

Kosasih, E. (2014). Jenis-Jenis Teks dalam Mata Pelajaran Bahasa Indonesia SMA/MA/ $S M K$. Bandung: Yrama Widia.

Roestiyah. (2008). Strategi Belajar Mengajar. Jakarta: Rineka Cipta

Somad, Abdul Adi. Aminudin, dan Irawan, Yudi. (2007). Aktif dan Kreatif Berbahasa Indonesia. Bandung: Pusat Perbukuan Departemen Pendidikan Nasioanal.

Sugiyono, Sugiyono. (2010). Metode penelitian kuantitatif dan kualitatif dan $R \& D$. ALFABETA Bandung.

Sumadiria, A. S. Haris. (2005). Menulis artikel dan tajuk rencana: panduan praktis penulis \& jurnalis professional. Simbiosa Rekatama Media.

Syamsi, Kastam dan Efendi, Anwar. (2010). Aku Mampu Berbahasa dan Bersastra Indonesia. Jakarta: Pusat Perbukuan Kementerian Pendidikan Nasional.

Yamin, Martinis \& Bansu I. Ansari. (2012). Taktik Mengembangkan Kemampuan Individual Siswa. Jakarta: Referensi. 